\title{
Incidence and significance of argentaffin and Paneth cells in some tumours of the large intestine
}

\author{
N. M. GIB BS \\ From Area Laboratory, St. Luke's Hospital, Guildford, and the Research Department, St. Mark's Hospital,
} London

SYNOPSIS The incidence of argentaffin and Paneth cells in epithelial tumours of the large intestine was

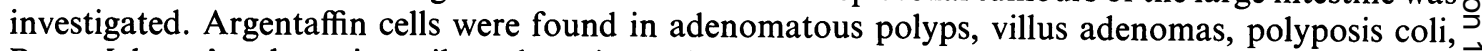
Peutz-Jehgers' polyps, juvenile polyposis, and adenocarcinomas. Paneth cells were not found in $z$ metaplastic or juvenile polyps.

The crypt unit was destroyed in neoplasia and argentaffin and Paneth cells occurred either as a result of sequestration or were taking part in the neoplastic process.

The crypt unit was retained in the disorders of epithelial growth. The identification of argentaffin and Paneth cells enabled the crypt to be defined and thus provided a useful, practical aid in the differentiation between neoplasms and disorders of epithelial growth.

Argentaffin cells are normally found at the base of the glands thoughout the entire large intestine. Paneth cells are scanty in the normal large bowel but may be found in the vicinity of benign and malignant tumours (Schmidt, 1905; Eklöf, 1914; Watson and Roy, 1960). They are also present in greatly increased numbers in some chronic inflammatory conditions, particularly ulcerative colitis (Paterson and Watson, 1961).

Feyrter (1931) found argentaffin cells in polyps of the large intestine but they were rather scarce. Hamperl (1927) examined 51 carcinomas of the intestinal tract and found argentaffin cells in three cases, but did not specify the site of these tumours. Paneth cells have been described in occasional adenomatous polyps (Schmidt, 1905; Kerr and Lendrum, 1936; Watson and Roy, 1960; Holmes, 1965) but Feyrter (1931) found that they were often present. Paneth cells have been reported only once in a case of colonic adenocarcinoma (Holmes, 1965).

There is no detailed study in the literature of argentaffin and Paneth cells in tumours of the large intestine. The object of this research is to investigate the incidence and significance of both types of cell in a large series of tumours from the large intestine representative of the histological varieties. Morson

Received for publication 20 March 1967.
(1962) discussed the classification of mucosal polyps $\frac{\mathrm{Q}}{\mathrm{D}}$ and for the purposes of this investigation the histological criteria described are followed, particularly $\overrightarrow{0}$ in relation to juvenile, metaplastic, and Peutz- $\exists$ Jehgers' varieties.

\section{MATERIAL}

The following tumours were investigated: adenomatous polyp, papillary adenoma, polyposis coli, adenocarcinoma, metaplastic polyp, Peutz-Jehgers' polyp, juvenile polyp, and juvenile polyposis. The material was obtained from $\delta$ the Department of Pathology, St. Mark's Hospital, ₹ London, and the Area Laboratory, Guildford and 0 Godalming Group Hospitals. Carcinoid tumours were excluded as they have been previously considered (Gibbs, 1963).

The tissues were fixed immediately in $10 \%$ formal $N$ saline. A single block was selected which included the centre of each tumour, and the tissue was processed and $N$ embedded in paraffin wax. Matching sections were cut at $\mathrm{N}$ $5 \mu$ and stained routinely by Ehrlich's acid haematoxylin 2 counterstained with eosin. Special stains included ${ }_{0}$ phloxine tartrazine, phosphotungstic acid haematoxylin $\frac{\mathscr{D}}{\Phi}$ (Mallory) and Gram stain (Weigert's modification) for $\stackrel{\oplus}{\oplus}$ Paneth cells; Fontana's silver impregnation, Schmorl's ? reaction, and the diazo method for enterochromaffin granules; and Perls's reaction for haemosiderin.

The following guide to the incidence of these cells in $\stackrel{?}{\stackrel{9}{+}}$ the tumours was used. The number of glands in each $5 \mu \stackrel{\mathbb{Q}}{\Omega}$ section which contained argentaffin and Paneth cells was 
counted where possible. In addition the total number of argentaffin and Paneth cells in each section was also counted. The average number of argentaffin and Paneth cells present in these glands was calculated and expressed as the number of cells per gland section. The results obtained from the positive tumours were added together and an average figure was calculated for each of the special groups of tumour under consideration.

Argentaffin cells were demonstrated by Fontana's silver impregnation and the diazo method for enterochromaffin granules. In general the criteria laid down by Lillie and Glenner (1960) were followed to obviate technical failure in the argentaffin reaction. Argentaffin cells were identified in the normal mucosa adjacent to the tumour in every case.

There is no specific stain for Paneth cells and many staining techniques have been described. In general phloxine tartrazine, phosphotungstic acid haematoxylin (Mallory) and Gram stain (modified Weigert) proved most reliable. However, occasionally the staining reactions were a little inconsistent and variable so that in practice matching sections were stained by each technique and compared. It was found that the granules of both argentaffin and Paneth cells stained a deep red with phloxine tartrazine although the characteristic size and position of the granules within the cells usually precluded any confusion. Phosphotungstic acid haemotoxylin stained Paneth granules a deep blue and argentaffin granules a diffuse smoky bluish-grey. The Gram (modified Weigert) stained Paneth cells a deep violet colour, while argentaffin granules generally were not visible. For the purpose of this investigation characteristic staining by each of these methods was considered necessary for the positive identification of Paneth cells.

\section{ADENOMATOUS POLYP}

Argentaffin cells were found in $19(41 \%)$ of the 46 adenomas examined (Fig. 1 and Table). They were located in the basal part of the gland when present in small numbers. Sometimes argentaffin cells were numerous and were scattered thoughout the tumour. Two tumours showed giant argentaffin cells (Fig. 2). Paneth cells were found in nine $(19 \%)$ of the 46 adenomas examined (Fig. 3) and in seven argentaffin cells were present. (Fig. 1 and Table).

\section{PAPILLARY OR VILLUS ADENOMA}

Argentaffin cells were found in nine (39\%) of the 23 tumours examined and they appeared normal. Paneth cells were present in eight tumours and in five they were very numerous (Figs. 1 and 4, and Table).

\section{POLYPOSIS COLI}

Twenty-three polyps from 11 cases of polyposis coli were examined and argentaffin and Paneth cells were found in eight adenomas (Fig. 1 and Table). Argentaffin and Paneth cells were not seen in four tumours which had undergone malignant transformation. One case was selected for detailed examination of adenomas from all parts of the large intestine but argentaffin and Paneth cells were found to be distributed fairly evenly in all parts of the bowel although the incidence was higher in the distal polyps which were, however, larger in size than the proximal polyps.

\section{MALIGNANT TUMOURS OF THE LARGE INTESTINE}

One hundred and fifty primary adenocarcinomas of the large bowel were examined. Argentaffin cells (Fig. 6) were found in three tumours (vermiform appendix, caecum, and rectum). Paneth cells were found in four tumours (Figs. 7a and 7b). In one case

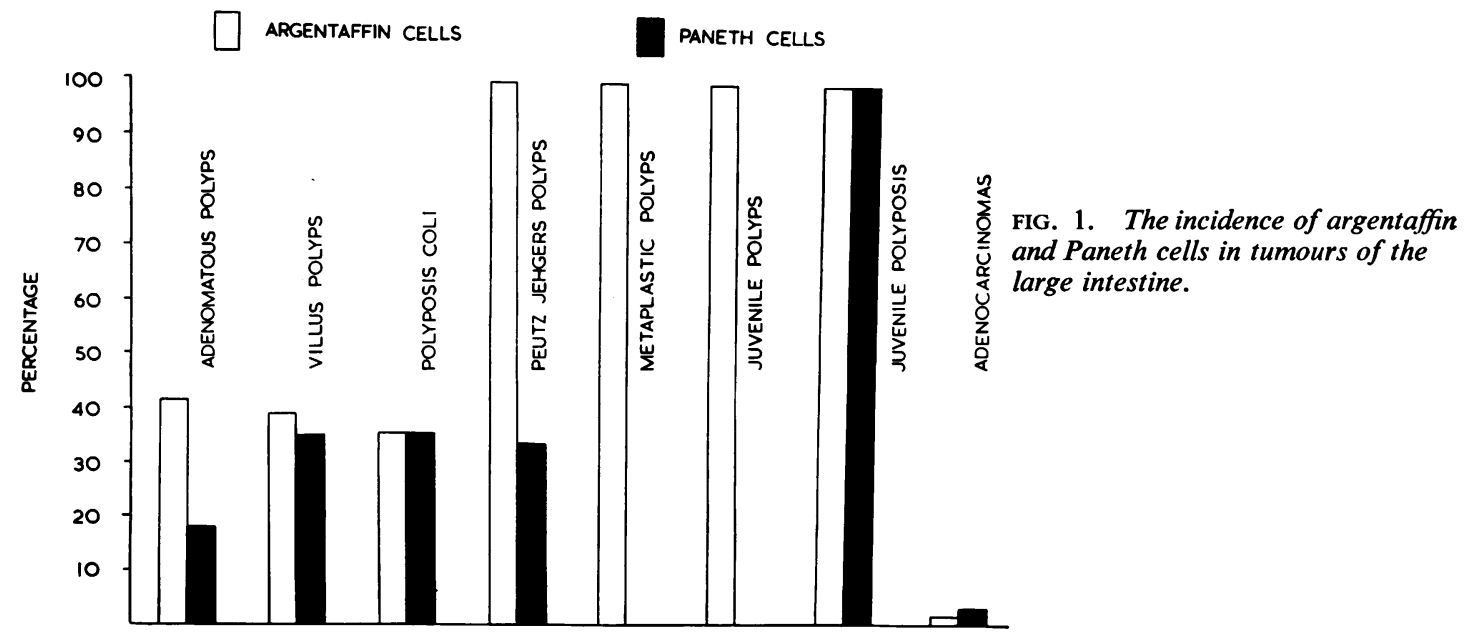




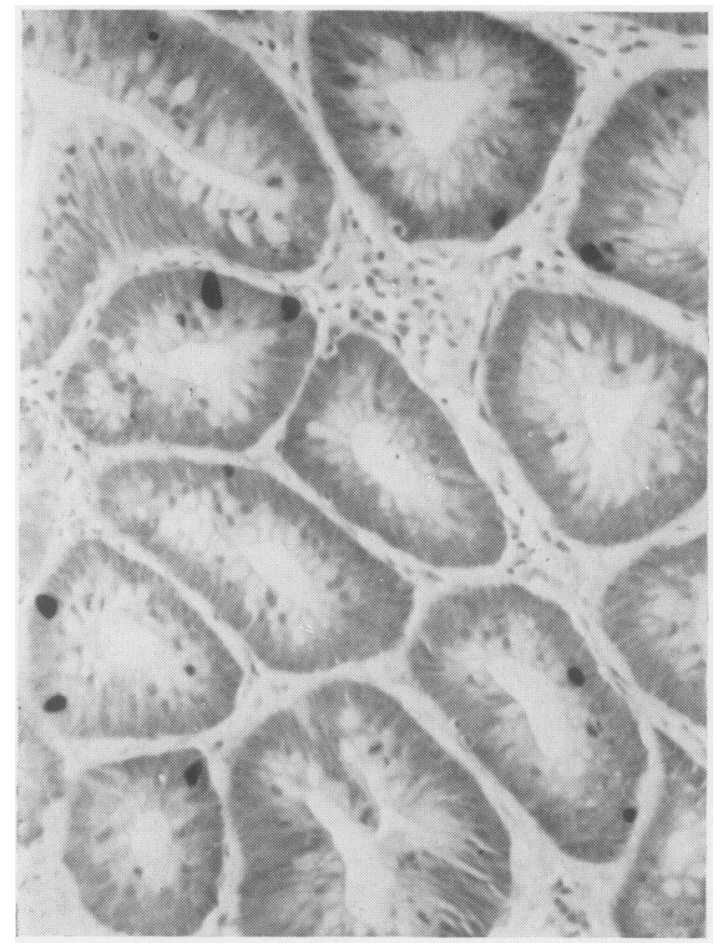

FIG. 3. Adenoma of rectum showing giant argentaffin cells. $($ Diazo $\times 100$. $)$

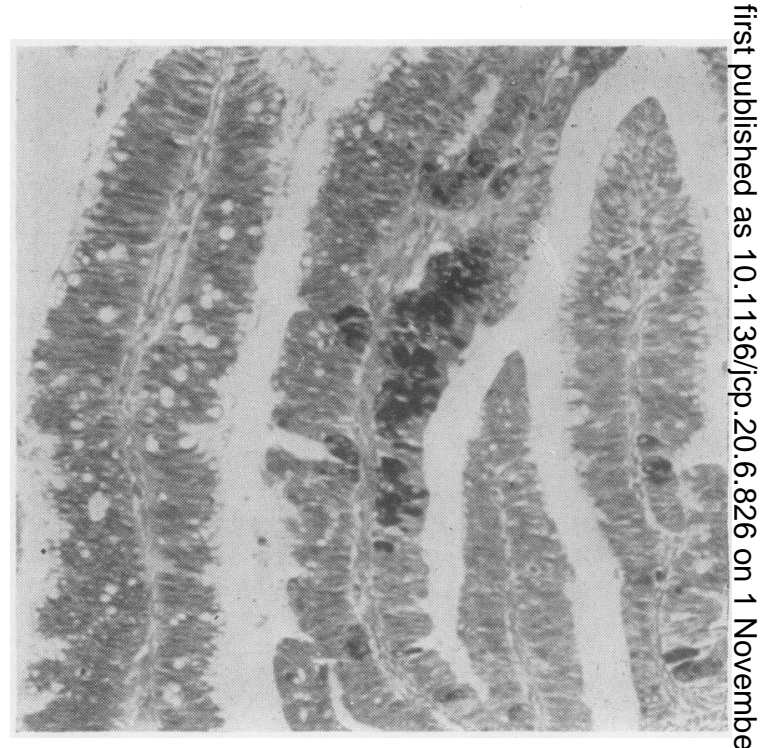

FIG. 4. Villus adenoma of rectum with Paneth cells. (Phloxine tartrazine $\times 80$.)

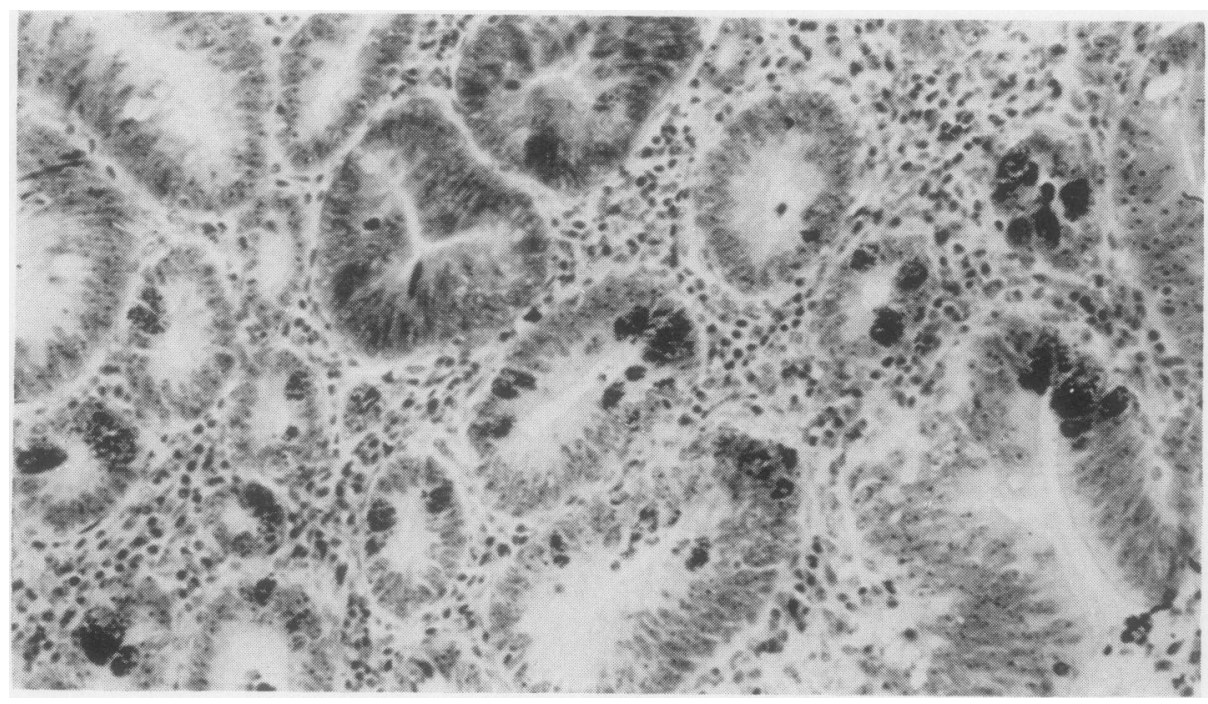

FIG. 2. Adenoma of rectum with Paneth cells. (Phloxine ô tartrazine $\times 100$. $) \mathrm{N}$ 


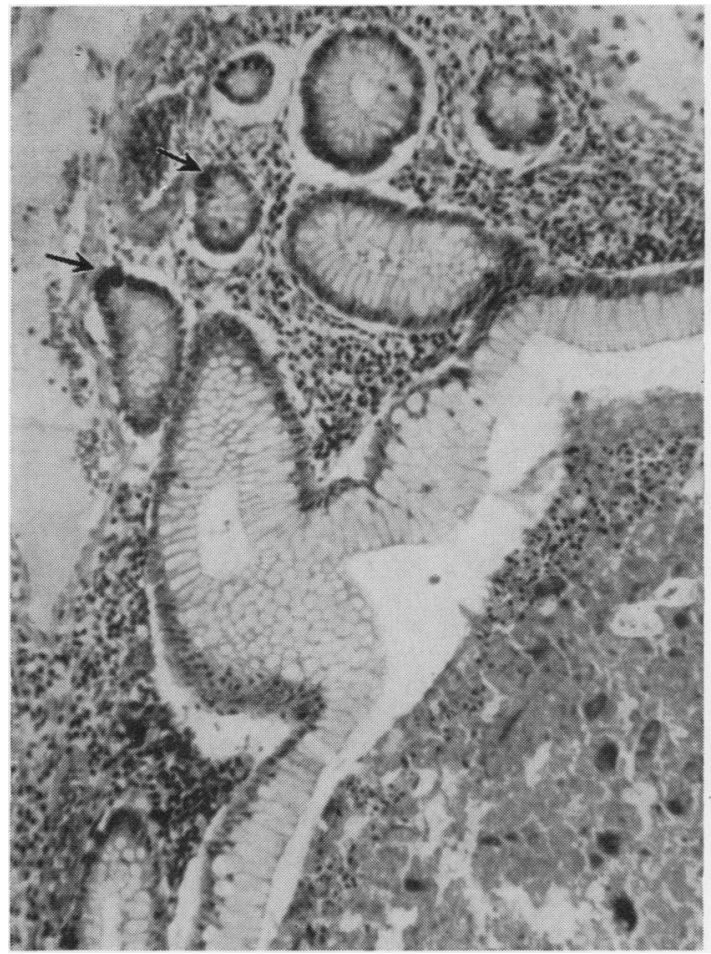

FIG. 5. Polyp from a case of juvenile polyposis showing multiple gland crypts, containing Paneth cells, opening into a cyst. (Phloxine tartrazine $\times 63$.)

(adenocarcinoma of the caecum) they were scanty and situated near the growing edge, and in the remainder (caecum, transverse colon, and sigmoid colon) they were found in great numbers (Figs. 7a and $7 \mathrm{~b}$ ). One of these seven tumours (adenocarcinoma of caecum) contained both argentaffin and Paneth cells. All the positive tumours produced copious secretion of mucin.

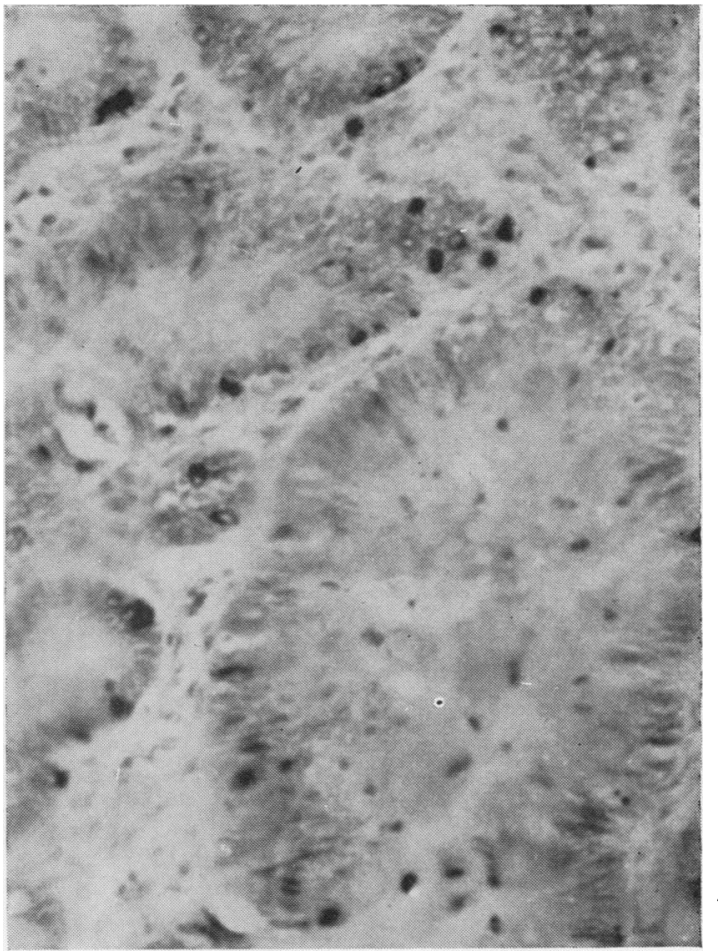

FIG. 6. Adenocarcinoma of rectum with numerous argentaffin cells. (Fontana's silver counterstained with saffranin $\times 150$.)

\section{METAPLASTIC POLYPS}

Thirty-four metaplastic polyps were examined (Fig. 1 and Table) and argentaffin cells were seen in the gland bases in similar numbers to the adjacent normal mucosa. Most of the argentaffin cells appeared enlarged and the cytoplasm was eosinophilic. Paneth cells were absent.

TABLE

\begin{tabular}{|c|c|c|c|c|c|}
\hline & \multirow[t]{2}{*}{ Cases } & \multicolumn{2}{|c|}{ Argentaffin Cells } & \multicolumn{2}{|c|}{ Paneth Cells } \\
\hline & & Tumours & Cell Count & Tumours & Cell Count \\
\hline Adenomatous polyp & 46 & 19 & $\begin{array}{l}20.6 \text { cells in } \\
11.6 \text { gland sections }\end{array}$ & 9 & $\begin{array}{l}20 \cdot 1 \text { cells in } \\
4.9 \text { gland sections }\end{array}$ \\
\hline Papillary adenoma & 23 & 9 & $\begin{array}{l}8.0 \text { cells in } \\
3.0 \text { gland sections }\end{array}$ & 8 & $\begin{array}{l}60.0 \text { cells in } \\
13.0 \text { gland sections }\end{array}$ \\
\hline Polyposis coli & 11 polyps & 8 & $\begin{array}{l}6.5 \text { cells in } \\
3.0 \text { gland sections }\end{array}$ & 8 & $\begin{array}{l}6.9 \text { cells in } \\
2.6 \text { gland sections }\end{array}$ \\
\hline Adenocarcinomas & 150 & 3 & Numerous & 4 & Numerous in 3 tumours \\
\hline $\begin{array}{l}\text { Metaplastic polyps } \\
\text { Peutz-Jehgers' syndrome }\end{array}$ & $\begin{array}{r}34 \\
9\end{array}$ & $\begin{array}{r}34 \\
9\end{array}$ & 23.2 cells per tumour & $\begin{array}{l}\mathbf{0} \\
3\end{array}$ & \\
\hline $\begin{array}{l}\text { Peutz-Jengers syndrome } \\
\text { Juvenile polyps }\end{array}$ & $\begin{array}{r}9 \\
15\end{array}$ & $\begin{array}{r}9 \\
15\end{array}$ & $\begin{array}{l}\text { In normal numbers } \\
10 \cdot 8 \text { cells in } \\
7 \cdot 7 \text { gland sections }\end{array}$ & $\begin{array}{l}3 \\
0\end{array}$ & In large numbers \\
\hline Juvenile polyposis & 3 & 3 & In small numbers & 3 & $\begin{array}{l}\text { In small numbers but } \\
\text { occasionally numerous }\end{array}$ \\
\hline
\end{tabular}




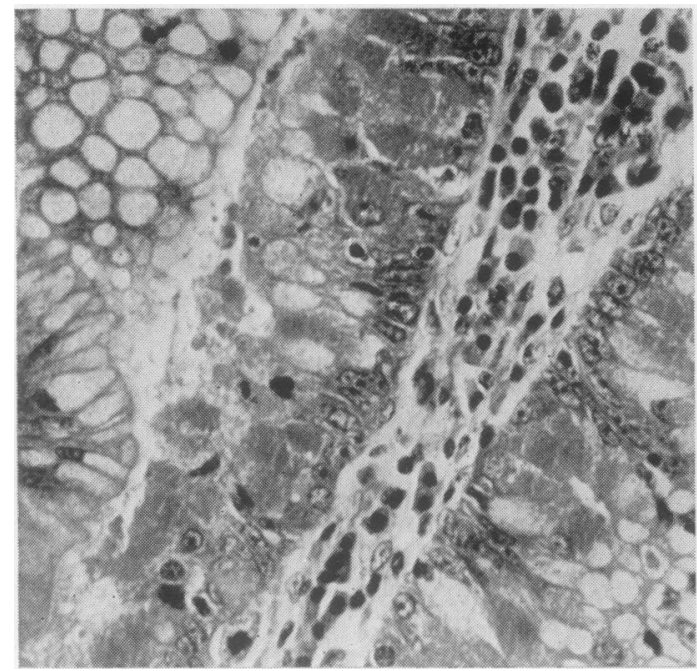

FIG. 7a.

FIG. 7. Adenocarcinoma of sigmoid colon with Paneth cells. (a) Ehrlich's haematoxylin and eosin showing numerous Paneth cells ( $\times 250)$; (b) Mallory's phosphotungstic acid haematoxylin $(\times 400)$.

PEUTZ-JEHGERS' SYNDROME

Nine polyps from nine cases of Peutz-Jehgers' syndrome were examined (Fig. 1 and Table). Argentaffin cells were found in the basal part of most glands and Paneth cells were also present in very large numbers in three polyps.

\section{JUVENILE POLYPS}

Fifteen polyps were examined and argentaffin cells were present in gland crypts in every case. The argentaffin cells appeared normal in size in spite of enlarged epithelial cells which formed the tumour. Paneth cells were not found.

\section{JUVENILE POLYPOSIS}

Polyps from three cases of juvenile polyposis (McColl, Bussey, Veale, and Morson, 1964) were examined. Argentaffin and Paneth cells were present in small numbers in the majority of polyps from each of the cases, and these cells were confined to the gland crypts (Fig. 5).

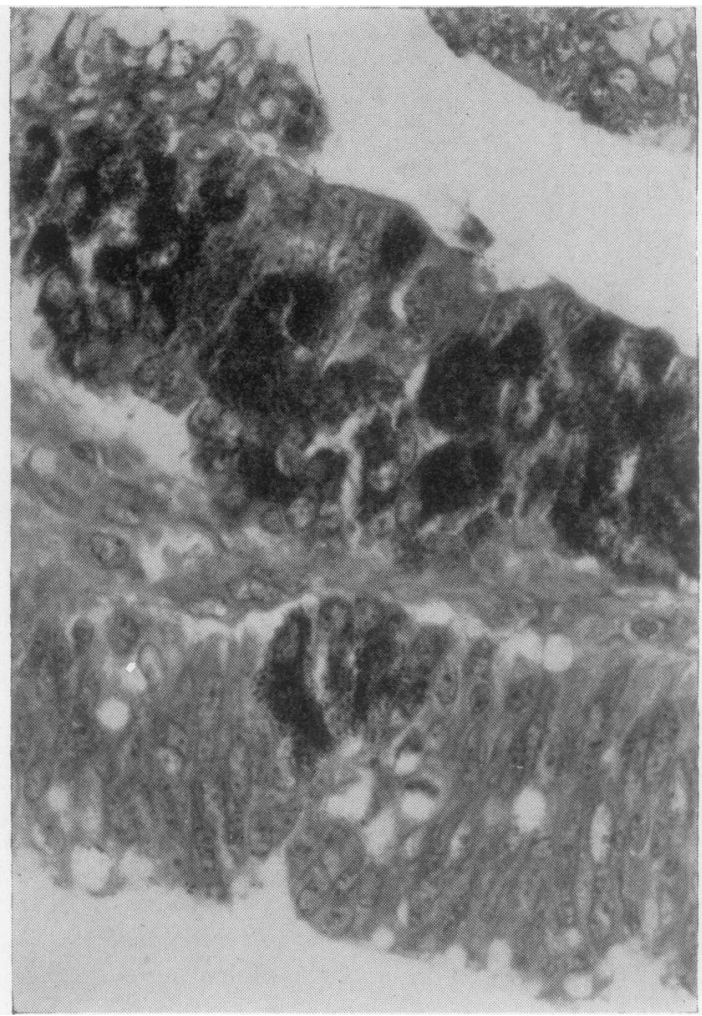

FIG. $7 \mathrm{~b}$.

\section{DISCUSSION}

Argentaffin cells are present in the gland crypts throughout the large intestine and occasional Paneth cells are also found, particularly in the caecum. The gland crypt is the site of normal cell regeneration 3 . and in neoplasia the normal basiglandular cells of $\delta$ the crypt are replaced by tumour cells. This occurs $₹$ as a primary process if the neoplasm is derived 0 directly from basiglandular cells and as a secondary process if the neoplasm arises elsewhere in the gland whence the crypt cells are displaced by tumour cells.

The adenomatous polyps of polyposis coli were $\mathcal{N}$ investigated by Lane and Lev (1963) who concluded $N$ that these neoplasms arose from the crypt cells, and N by Cole and McKalen (1963) who found that they ${ }^{\omega}$ originated at the superficial part of the gland. This apparent contradiction may be resolved by the hypothesis that neoplasia may commence in both parts of the gland and that the tumours showing numerous argentaffin and/or Paneth cells are derived ${ }^{\circ}$ from the basiglandular cells of the crypt. It is not $\mathbb{D}$ surprising that tumoursarising from the basiglandular $\frac{O}{1}$ cells of the crypt produce argentaffin and Paneth 
cells by differentiation as these cells are present in normal crypts. Neoplastic argentaffin and Paneth cells may be expected to be scattered throughout the tumour instead of being confined to the crypts. The presence of occasional argentaffin and Paneth cells in gland crypts occupied by neoplastic cells is explained by the occasional survival of normal basiglandular cells which are 'sequestered' amidst neoplastic cells. Sequestration accounts for the presence of argentaffin cells in five of the 19 cases $(26 \%)$ of adenomatous polyps and eight of the nine cases $(89 \%)$ of villous adenomas. A similar explanation accounts for the presence of Paneth cells in three of the nine cases (33\%) of adenomatous polyp and one of the eight cases of villus adenoma (12\%). In others, argentaffin and Paneth cells are scattered throughout the tumours, sometimes in great numbers, and it is concluded that these cells are part of the neoplastic process. Mitoses in Paneth cells and argentaffin cells are not seen, possibly because the characteristic granules are not present in the dividing stage. However, neoplastic argentaffin and Paneth cells show loss of orientation and bizarre forms. The majority of the tumours with argentaffin and Paneth cells showed prominent mucin secretion in some parts illustrating their differentiation.

Neoplastic argentaffin cells were present less commonly in the villous adenoma than in the adenomatous polyp, while the reverse was found in the case of Paneth cells. These findings do not suggest any difference between the malignant potential of the two tumours. However, no clear differences were present between the solitary adenomatous polyp and the multiple adenomatous polyps of familial polyposis.

In contrast to the tumours already described where the cytology of the gland crypt is destroyed, the remaining tumours are distinguished by the retention of the basic gland crypt unit. Argentaffin and Paneth cells are located in the crypt and their presence provides a useful aid in the identification and the assessment of the gland crypt. The gland crypts in metaplastic polyp, Peutz-Jehgers' polyp, juvenile polyp, and juvenile polyposis are easily recognized by this method even though they may be greatly distorted. This distortion is minimal in metaplastic polyp, but very conspicuous in juvenile polyposis (Fig. 5) where it is caused by abnormal and florid development of the superficial part of the gland. Paneth cells are present in juvenile polyposis but absent in the solitary juvenile polyp suggesting a difference in the growth processes, even though the polyps have many similarities. The cytology of the crypt in some Peutz-Jehgers' polyps and in juvenile polyposis where Paneth cells are found suggests a local variation in crypt metabolism. These findings support the view that this group of tumours arises as an anomaly of growth.

I wish to thank Dr. B. C. Morson for his advice and encouragement and the consultant staff of the Royal Surrey County Hospital and St. Marks' Hospital for permission to study their cases. For technical assistance I am grateful to Mrs. R. M. Shrubb, Mr. Lloyd Soodeen, Mr. Norman Mackie, and Mr. L. W. French.

The expenses of this investigation were defrayed from a research grant from the South West Metropolitan Regional Hospital Board, and from a block grant to the Research Department of St. Mark's Hospital from the British Empire Cancer Campaign.

\section{REFERENCES}

Cole, J. W., and McKalen, A. (1963). Cancer (Philad.), 16, 998. Eklöf, H. (1914). Chondriosomenstudien an den Epithel-und Drüsenzellen des magen- Darmkanals und den Oesophagus-Drüsenzellen bei Sängetieren. J. F. Bergmann, Wiesbaden. (also Anat. Hefte, 51, 1.)

Feyrter, F. (1931). Beitr. path. Anat., 86, 663.

Gibbs, N. M. (1963). J. clin. Path., 16, 206.

Hamperl, H. (1927). Virchows Arch. path. Anat., 266, 509.

Holmes, E. J. (1965). Cancer (Philad.), 18, 1416.

Kerr, A. B., and Lendrum, A. C. (1936). Brit. J. Surg., 23, 615.

Lane, N., and Lev, R. (1963). Cancer (Philad.), 16, 751.

Lillie, R. D., and Glenner, G. G. (1960). Amer. J. Path., 36, 623.

McColl, I., Bussey, H. J. R., Veale, A. M. O., and Morson, B. C. (1964). Proc. roy. Soc. Med., 57, 986.

Morson, B. C. (1962). Dis. Colon Rect., 5, 337.

Paterson, J. C., and Watson, S. H. (1961). Amer. J. Path., 38, 243.

Schmidt, J. E. (1905). Arch. mikr. Anat., 36, 12.

Watson, A. J., and Roy, A. D. (1960). J. Path. Bact., 80, 309. 